\title{
Abrasión de superficies de azulejos cerámicos esmaltados
}

\author{
L. ESPOSITO, A. TUCCI \\ Centro Cerámico Italiano, 40138 Bolonia, Italia
}

\begin{abstract}
Las características de la propia superficie de los azulejos cerámicos esmaltados tiene una influencia considerable en la respuesta mecánica de éstos a las distintas tensiones provenientes del entorno. De acuerdo con esto, uno de los parámetros más importantes que definen la correcta utilización de estos productos es el comportamiento ante el desgaste de la propia superficie. Debido a que la capa de esmalte es la conexión física entre el entorno y el cuerpo cerámico, sus características también determinan vida útil del azulejo. El objetivo de la investigación de la que damos cuenta aquí fue calcular la influencia de la dureza, resistencia a la fractura y porosidad de la capa de esmalte en el comportamiento ante el desgaste de la propia superficie de los azulejos cerámicos esmaltados. Los resultados obtenidos muestran una clara relación entre las características de la capa de esmalte y la eliminación del material en forma de pérdida de peso normalizada, que puede ser considerada como una herramienta útil para predecir el comportamiento ante el desgaste de estos productos.
\end{abstract}

Palabras clave: azulejo cerámico esmaltado, dureza, resistencia a la fractura, porosidad, abrasión de la superficie.

\section{Surface Abrasion of Glazed Ceramic Tiles}

The characteristics of the proper surface of glazed ceramic tiles have a considerable influence on their mechanical response to the various stresses coming from the environment. In this regard, one of the most important parameters to define the correct use of these products is the wear behaviour of the proper surface. Since the glaze layer is the physical interface between the environment and ceramic body, its characteristics also determine the service life of the tile. The objective of the research reported here was to assess the influence of hardness, fracture toughness and porosity of the glaze layer on the wear behaviour of the proper surface of glazed ceramic tiles. The results obtained show a clear relationship between the characteristics of the glaze layer and the material removal in the form of normalised weight loss, which can be considered a useful tool to predict the wear behaviour of these products.

Key words: Glazed ceramic tile, Hardness, Fracture toughness, Porosity, Surface abrasion

\section{INTRODUCCIÓN}

La resistencia al desgaste de las baldosas cerámicas es un parámetro importante al elegir el tipo de azulejo, tanto si está esmaltado como si no lo está, que se va a utilizar en un entorno concreto. Estos componentes constructivos son muy sensibles a las tensiones producidas por la circulación de peatones, el paso de carros o vehículos de automoción, impactos, químicos, agentes de limpieza, etc. En concreto, los objetos que caen y las partículas muy puntiagudas representan una fuente continua e incontrolable de agrietamiento de la superficie y eliminación del material. Dicho deterioro es acumulativo y determina la degradación irreversible de la resistencia y las características estéticas de la propia superficie de los azulejos cerámicos (1). Como el esmalte es propenso a agrietarse, rayarse y astillarse, es importante definir la correcta utilización de estos productos. En otras palabras, las propiedades de los azulejos deben ser las adecuadas para el entorno en que se instalan. A causa de que es muy probable que se produzca este tipo de deterioro y a menudo inevitable, las características de la capa de esmalte se convierten en parámetros críticos a la hora de determinar el comportamiento y la vida útil de los azulejos cerámicos esmal-

\section{INTRODUCTION}

The wear resistance of ceramic floor tiles is an important parameter when choosing the type of tile, both glazed and unglazed, to be used in a particular environment. These building components are very sensitive to the stresses induced by pedestrian traffic, passage of carts or automotive vehicles, impacts, chemicals, cleaning agents, etc. In particular, falling objects and hard sharp particles represent a continuous and uncontrollable source of surface cracking and material removal. Such damage is cumulative and determines irreversible degradation of the strength and aesthetic characteristics of the proper surface of ceramic tiles (1). Since the glaze is prone to cracking, scratching and chipping, it becomes important to define the correct use of these products. In other words, the properties of the tiles must be suitable for the environment in which they are installed. Because this type of damage is highly probable and often inevitable, the characteristics of the glaze layer become critical parameters in determining the performance and service life of glazed ceramic tiles. Indeed, the degradation of the proper surface of the tiles involves both the integrity and functional aspects of the tiled surface. Although 
TABLA I - ClASIFICACIÓN EN Y PROCESO DE ESMALTADOS INDUSTRIAL DE LOS PRODUCTOS.

TABLE I - EN CLASSIFICATION AND INDUSTRIAL GLAZING PROCESS OF THE PRODUCTS.

\begin{tabular}{|c|c|c|c|}
\hline Sample & $\begin{array}{c}\text { Water } \\
\text { absorption, } \%\end{array}$ & Class EN & $\begin{array}{c}\text { Glazing } \\
\text { process }\end{array}$ \\
\hline 1 & 4.1 & BIIa & Wet application \\
2 & 2.2 & BI & Firestream \\
3 & 3.6 & BIIa & Wet application \\
4 & 3.8 & BIIa & Wet application \\
5 & 2.4 & BI & Wet application \\
6 & 3.0 & BI & Wet application \\
\hline
\end{tabular}

tados. Es cierto que la degradación de la propia superficie de los azulejos, implica tanto los aspectos de integridad y funcionales de la superficie azulejada. Aunque el comportamiento de la propia superficie de los azulejos cerámicos esmaltados es importante a la hora de determinar el comportamiento y la vida útil de la superficie azulejada, la razón más probable por la que los proveedores no hayan llevado a cabo una investigación sistemática del problema es probablemente el bajo valor intrínseco de estos productos.

La resistencia a la abrasión de un material depende de varios parámetros y es un fenómeno que no es fácilmente cuantificable y casi siempre resulta difícil de definir. Como bien es sabido, en cerámica un fenómeno abrasivo, es decir, un proceso de desgaste, provoca degradación mecánica en forma de estrías, rayas, cortes y eliminación de material (2-5). Para calcular el volumen de material eliminado por acciones abrasivas y/o erosivas, se proponen diferentes modelos teóricos, que dependen principalmente de la dureza y la resistencia a la fractura. Estos modelos, basados en el deterioro producido por el paso de cada una las partículas muy afiladas que se deslizan por la superficie del azulejo que sobrepasa el límite mínimo de fractura, no tienen en cuenta de manera apropiada otros parámetros relacionados con la microestructura (8-10).

Partiendo de estas observaciones y considerando también la estrecha relación con las característica de la superficie de los azulejos cerámicos esmaltados, la presente investigación se dirigió hacia el estudio de las relaciones entre la eliminación de material que resulta del test de abrasión del standard PEI, con algunas características físico-mecánicas de la capa de esmalte, incluyendo la dureza de los Vickers, la resistencia a la fractura y la porosidad. Este enfoque, que se aplicó previamente a la investigación del comportamiento ante el desgaste de la cerámica avanzada por abrasión húmeda y erosión $(8,12)$, también llevó a algunas conclusiones interesantes para los materiales que se investigan en el presente estudio.

\section{MATERIALES Y MÉTODOS}

Para el presente estudio se eligieron azulejos cerámicos esmaltados mediante monococción que están disponibles en el mercado y a lo largo del texto reciben el nombre de muestras 1, 2, 3, 4, 5 y 6. Estos productos se clasificaron según la absorción de agua que mostraron en el procedimiento de ensayo especificado en la Norma Europea EN 99. Los resultados obte-
TABla II - DUREZA MEDIA DE LA CAPA DE ESMALTE, DE LA DUREZA DE LOS VICKERS Y DE LA RESISTENCIA A LA FRACTURA DE LOS PRODUCTOS.

TAble II - AVERAGE GLAZE LAYER THICKNESS, ViCKERS HARDNESS AND FRACTURE TOUGHNESS OF THE PRODUCTS.

\begin{tabular}{|c|c|c|c|}
\hline Sample & $\begin{array}{c}\text { Glaze layer } \\
\text { thickness }(\mathbf{m m})\end{array}$ & $\mathbf{H V}(\mathrm{GPa})^{*}$ & $\mathbf{K}_{\mathrm{IC}}(\mathbf{M P a} \sqrt{\mathbf{m}})$ \\
\hline 1 & 0.276 & 5.6 & $1.00^{\star}$ \\
2 & 0.868 & 5.5 & $1.23^{*}$ \\
3 & 0.373 & 5.5 & $1.13^{\star}$ \\
4 & 0.124 & 5.7 & $0.92^{\wedge}$ \\
5 & 0.343 & 5.4 & $0.81^{\wedge}$ \\
6 & 0.268 & 5.6 & $0.80^{\star}$ \\
\hline
\end{tabular}

*Indentation load: $\mathrm{P}=9.81 \mathrm{~N}$.

^Indentation load: $\mathrm{P}=4.91 \mathrm{~N}$.

the behaviour of the proper surface of glazed ceramic tiles is important in determining the performance and service live of the tiled surface, the low intrinsic value of these products is probably the reason why producers have not carried out a systematic investigation of the problem.

The abrasion resistance of a material depends on several parameters and is a phenomenon that is not easily quantified and is almost always difficult to define. As is well known, in ceramics an abrasive phenomenon, i.e. a machining process, induces mechanical degradation in the form of grooves, scratches, cuts and material loss (2-5). To quantify the volume of material removed by abrasive and / or erosive actions, different theoretical models, essentially depending on hardness and fracture toughness, have been suggested $(6,7)$. These models, based on the damage induced by the passage of each individual hard sharp particle sliding across the tile surface that exceeds the fracture threshold load, do not adequately take into account other parameters related to the microstructure (8-10).

Starting from these observations and also considering the very close relationship with the surface characteristics of glazed ceramic tiles (11), the research reported here was directed towards studying the relationships between material removal, resulting from the standard PEI abrasion test, with some physical-mechanical characteristics of the glaze layer, including Vickers hardness, fracture toughness and porosity. This approach, previously applied to the investigation of the wet abrasive and erosive wear behaviour of advanced ceramics $(8,12)$, also led to some interesting conclusions for the materials investigated in the present study.

\section{MATERIALS AND METHODS}

Commercially available single-fired glazed ceramic tiles were chosen for the present study and throughout the text are denoted as samples 1, 2, 3, 4, 5 and 6 . The products were classified on the basis of their water absorption determined following the test method specified in the European Standard EN 99. The results obtained together with the glazing technology used in the production of the tiles are reported in table I.

The hardness of the proper surface, average value of at least ten valid impressions, was evaluated using a hardness tester (Zwick, 3212, Germany) equipped with a Vickers indenter and the following indentation loads: 1.95, 2.94, 4.90, 9.81 and 
TABLA III - POROSIDAD Y TAMAÑO MEDIO DE LOS POROS.

TABLE III - Porosity AND AVERAGE PORES SIZE.

\begin{tabular}{|c|c|c|}
\hline Sample & Porosity (\%) & $\begin{array}{c}\text { Average pores } \\
\text { size }(\mathbf{m m})\end{array}$ \\
\hline 1 & 2.87 & 8.47 \\
2 & 0.70 & 8.30 \\
3 & 5.32 & 11.30 \\
4 & 10.20 & 16.50 \\
5 & 9.20 & 35.50 \\
6 & 11.80 & 12.30 \\
\hline
\end{tabular}

nidos, junto con la tecnología de esmaltado utilizada en la producción de los azulejos aparecen en la tabla 1.

La dureza de la propia superficie, el valor medio de al menos diez impresiones válidas, se evaluó mediante la prueba de dureza (Zwick, 3212, Alemania) equipado con un indentador Vickers y las siguientes cargas de impresión: 1.95, 2.94, $4.90,9.81$ y $19.62 \mathrm{~N}$. Los valores de dureza que aparecen en la tabla II se refieren a una carga de impresión de $9.81 \mathrm{~N}$, aquélla en la que se comprobó que el comportamiento de la dureza era constante. El espesor de la capa de esmalte se determinó mediante observaciones de secciones cruzadas pulidas de muestras adecuadas en el microscopio óptico. La comparación entre estos valores y la profundidad de las impresiones de los Vickers (13) permitieron desechar la contribución del cuerpo cerámico a la dureza.

La resistencia a la fractura $\mathrm{K}_{\mathrm{IC}}$ se calculó mediante la ecuación de Lawn y otros (14); se midió la extensión de las grietas provocada por las esquinas de las impresiones y se dio por sentado que los módulos de elasticidad eran los siguientes: $\mathrm{E}$ $=58 \mathrm{Gpa}$ (15). Además, es posible desechar la influencia del cuerpo cerámico en la resistencia a la fractura a partir de la observación en el microscopio, ya que las grietas de valor medio radial aumentaron únicamente en la capa de esmalte.

La porosidad en la capa de esmalte se evaluó según la observación de las mismas secciones cruzadas pulidas con un microscopio óptico en la luz reflejada; las imágenes digitalizadas se procesaron utilizando un analizador de imágenes (16). En la tabla III aparece la porosidad en porcentaje y el tamaño medio de los poros.

La resistencia a la abrasión de la superficie de los azulejos cerámicos esmaltados se determinó de acuerdo con el método PEI (17). Esta prueba consiste en la abrasión de la propia superficie de las muestras adecuadas cortadas de azulejos esmaltados para probarlas, cuyas dimensiones son 100x100mm, mediante una carga abrasiva estandarizada contenida en un recipiente de metal. El medio de desgaste consiste en bolas de acero de varios diámetros, óxido de aluminio y agua desmineralizada. El sistema rota con una excentricidad de $22.5 \mathrm{~mm}$ para un número bien nutrido de revoluciones, que corresponden a diferentes etapas de abrasión. El nivel de degradación de la superficie se basa, mediante la observación de las muestras desgastadas y los azulejos recibidos, en el número más bajo de revoluciones que produce una variación visual aparente en el brillo o el color. Para cada producto se determinó la clase de abrasión PEI, tal como se recomienda en la Norma Europea
TABLA IV - ClASIFICACIÓN PEI Y PÉRDIDA DE PESO NORMALIZADA (SIGLAS EN INGLÉS, NWL).

TABLE IV - PEI CLASSIFICATION AND NORMALISED WEIGHT LOSS, NWL.

\begin{tabular}{|c|c|c|c|}
\hline Sample & PEI class & $\begin{array}{r}\text { NWL } \mu \mathrm{g} / \mathbf{m m}^{\mathbf{2}} \\
\mathbf{( 6 0 0 0} \mathbf{~ r e v . )}\end{array}$ & $\begin{array}{c}\text { NWL } \mu \mathrm{g} / \mathbf{m m}^{\mathbf{2}} \\
\mathbf{( 1 2 0 0 0} \mathbf{~ r e v . )}\end{array}$ \\
\hline 1 & IV & 19.63 & 44.47 \\
2 & IV & 1.56 & 3.01 \\
3 & IV & 17.85 & 33.90 \\
4 & II & 26.28 & 51.89 \\
5 & II & 29.57 & 55.00 \\
6 & II & 26.39 & 57.13 \\
\hline
\end{tabular}

$19.62 \mathrm{~N}$. The hardness values reported in table II are relative to an indentation load of $9.81 \mathrm{~N}$, the load at which the hardness behaviour was found to be constant. The thickness of the glaze layer was determined via optical microscope observations of polished cross sections of suitable samples. The comparison between these values and the depth of the Vickers impressions (13) allowed to exclude the contribution to hardness of the ceramic body.

Fracture toughness $\mathrm{K}_{\mathrm{IC}}$ was calculated using the equation of Lawn et al. (14); the length of the cracks originating from the corners of the impressions were measured and the modulus of elasticity was assumed to be the following: $\mathrm{E}=58 \mathrm{GPa}$ (15). Furthermore, from the microscopic observation it is possible to exclude the influence of the ceramic body on fracture toughness, because the median-radial cracks grew only within the glaze layer.

The porosity within the glaze layer was evaluated on the basis of observation of the same polished cross sections with an optical microscope in reflected light; the digitised images were processed using an image analyser (16). Reported in table III are the porosity in percent and the average size of the pores.

The resistance to surface abrasion of the glazed ceramic tiles was determined according to the PEI method (17). This test consists in the abrasion by a standardised abrasive charge, contained in a metal holder, of the proper surface of suitable specimens, $100 \times 100 \mathrm{~mm}$ in dimensions, cut from the glazed tiles to be tested. The abrading medium consists of steel balls of various diameter, aluminium oxide and demineralised water. The system rotates with an eccentricity of $22.5 \mathrm{~mm}$ for well-fixed numbers of revolutions, corresponding to different abrasion stages. The level of surface degradation is based, by the observation of both the abraded specimens and the as received tiles, on the lowest number of revolutions that induces an apparent visual variation in gloss or colour. For each product, the PEI abrasion class, as recommended in the European Standard EN 154, was determined. Furthermore, the material loss after the two stages of 6000 and 12000 revolutions was determined. The choice of these abrasion stages was based on the barely meaningful weight loss results obtained for individual specimens subjected to the stages specified by the Standard. Indeed, to correctly measure the material loss and recognise the wear behaviour of the glaze layer, it was found that 1500 revolutions, the more severe stage specified by the Standard, can still be considered a transient phase. The 
EN 154. Además, se determinó la pérdida de material después de dos etapas de 6000 y 12000 revoluciones. La elección de estas etapas de abrasión se basó en los resultados de pérdida de peso apenas significativos obtenidos de muestras individuales sujetas a etapas especificadas por la Norma. En efecto, con el fin de medir correctamente la pérdida de peso y reconocer el comportamiento ante el desgaste de la capa de esmalte, se descubrió que 1500 revoluciones, la etapa más dura especificada por la Norma, todavía se puede considerar como una fase transitoria. Los resultados de la pérdida de peso normalizada (NWL) expresados como el ratio del área desgastada de la pérdida de peso total, $\left(\mu / \mathrm{mm}^{2}\right)$ se muestran en la tabla IV.

\section{RESULTADOS Y DISCUSIÓN}

Los valores de porosidad de las capas de esmalte de las muestras testadas, tabla III, varían considerablemente, y dependen de las características químicas y el procesamiento tecnológico del azulejo. La muestra 2, por ejemplo, tiene una porosidad muy baja en la capa de esmalte así como un gran número de poros atrapados en el engobe, Figura $1^{a}$. Este aspecto se puede atribuir principalmente a la tecnología de esmaltado completamente diferente que se ha utilizado para este producto, corriente de fuego en lugar de aplicación húmeda. En cualquier caso, el tamaño medio de los poros de todas las muestras es bastante coherente, figuras $1 \mathrm{a}$ y $\mathrm{b}$.

Los resultados que aparecen en la tabla II muestran claramente que la dureza de los Vickers de la superficie propia es bastante independiente tanto de la tecnología de esmaltado como de la porosidad de la capa de esmalte. A diferencia de otros materiales cerámicos, esta última característica, ya encontrada en un estudio anterior (11), se debe principalmente al hecho de que los poros presentes en las capas de esmalte son normalmente más grandes y/o del mismo tamaño que la impresión. Así pues, cuando el indentador entra en contacto directa o indirectamente con uno de ellos, el material se reblandece y la medida no es válida.

Por el contrario, la resistencia a la fractura, más sensible a las características microestructurales (18), muestra un incremento bastante definido con la compactación creciente del esmalte, tal como aparece en la figura 2 . $\mathrm{K}_{\mathrm{IC}}$ el valor máximo en la muestra 2, caracterizada por la porosidad más baja. Los niveles de porosidad tienen un ligero efecto sobre la resistencia a la fractura, como se muestra en las muestras 1 y 3 , mientras que un aumento considerable en la porosidad del esmalte provoca su caída drástica.

El NWL de los azulejos que se ha examinado, tabla IV, muestra una dependencia importante en la porosidad y la resistencia a la fractura, tal como aparece en las figuras 3 y 4 , respectivamente. Un descenso en la porosidad cerrada y un aumento en la resistencia a la fractura mejoran la resistencia al desgaste por fricción. En las dos estructuras, la

rapicia

results of the normalised weight loss (NWL) expressed as the total weight loss-abraded area ratio $\left(\mathrm{mg} / \mathrm{mm}^{2}\right)$ are reported in table IV.

\section{RESULTS AND DISCUSSION}

The porosity values of the glaze layers of the tested samples, table III, vary considerably, and depend on the chemical characteristics and technological processing of the tile. Sample 2, for example, has a very low porosity in the glaze layer as well as a large number of pores trapped in the engobe, Figure 1a. This aspect can be essentially attributed to the completely different glazing technology used for this product, firestream instead of wet application. In any case, the average pores size of all the samples is rather consistent, figures $1 \mathrm{a}$ and $\mathrm{b}$.

The results reported in table II clearly show that the Vickers hardness of the proper surface is quite independent of both the glazing technology and the porosity of the glaze layer. Unlike other ceramic materials, this latter characteristic, already found in a previous study (11), is essentially due to the fact that the pores present in the glaze layers are generally larger and / or of the same size as the impression. So, when the indenter directly or indirectly interferes with one of them, the material collapses and the measurement is not valid.

On the contrary, fracture toughness, more sensitive to microstructural features (18), shows a rather definite increase with increasing compactness of the glaze, as reported in figure 2. Indeed, $\mathrm{K}_{\mathrm{IC}}$ reaches the maximum value in sample 2, charac- 
dependencia no es lineal, como también se encuentra en el desgaste erosivo húmedo de las cerámicas aluminosas (8).

Además, se debe hacer constar que a pesar de la conocida dependencia en la dureza que muestran los materiales frágiles $(6,7)$, se descubrieron diferentes repuestas de desgaste, tabla IV, incluso a pesar de que la dureza de la superficie de las muestras testadas era bastante parecida. Aparentemente este resultado es sorprendente. Es cierto, mientras que los valores de dureza de los Vickers de la superficie propia de los azulejos cerámicos esmaltados es bastante semejante (11), las características físicomecánicas del material a granel en una sección cruzada de la capa de esmalte son bastante diferentes, dependiendo de la tecnología de esmaltado, de la composición de la pasta mezclada, de las características del esmalte, de la reacciones químicas y del ciclo de cocción. En cuanto a esto, desde un valor de dureza máximo cerca de la superficie, muy parecido al encontrado en la propia superficie, en la sección cruzada de un azulejo esmaltado la dureza de la capa de esmalte desciende continuamente, llegando a un valor mínimo en la capa intermedia de la pasta de la capa cerámica esmaltada (19). Incluso con mecanismos de fractura diferentes cerca de la capa intermedia, este comportamiento tiene lugar tanto en los azulejos cerámicos de monococción como en los de bicocción. Por esta razón, después de retirar las primeras capas de la superficie compactas y finas, sin poros, la carga abrasiva PEI entra en contacto progresivamente con un material menos denso, caracterizado, al contrario de lo que ocurre con la superfiice, por dos distribuciones de defectos distintas: i) los defectos que ya existían debido a la porosidad atrapada en la capa de esmalte durante el proceso de cocción y, ii) el deterioro provocado, las rayas, cortes y eliminación de material, como consecuencia de la acción abrasiva. Mientras que la porosidad, generalmente debida a los poros esféricos, y el tamaño medio del poro se pueden evaluar fácilmente, el desgaste producido por el deterioro es difícil de detectar y en cualquier caso es diferente en la morfología y la geometría. El desgaste producido por el deterioro es una función de las características de los materiales y de los parámetros de ensayo, en este caso el número de revoluciones.

El NWL después de 6000 revoluciones muestra una tendencia parecida a la registrada después de 12000, mostrando que la fase transitoria relacionada con la eliminación de las prime-

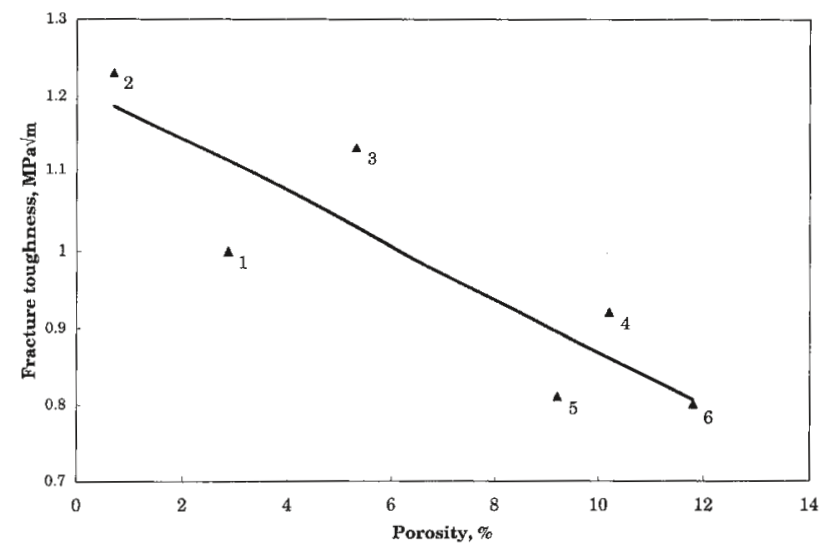

Figura 2 - Resistencia a la fractura como una función de la porosidad de las capas de esmalte: los números de la estructura corresponden a las muestras.

Figure 2 - Fracture toughness as a function of the porosity of the glaze layers: the numbers in the plot correspond to the samples. the glaze layer continually decreases, reaching a minimum value at the glaze layer-ceramic body interface (19). Even with different fracture mechanisms near the interface, this behaviour takes place in both single-fired and double-fired ceramic tile. Thus, after the first thin compact surface layers, without pores, have been removed, the abrasive PEI charge progressively comes into contact with less dense material, characterised, contrary to the surface, by two different flaw distributions: i) the pre-existing flaws due to the porosity trapped in the glaze layer during the firing process and, ii) the induced damage, scratches, cuts and material removal, as a consequence of the abrasive action. While the porosity, generally due to spherical pores, and the average pore size can be easily evaluated, the wear induced damage is difficult to detect and in any case different in morphology and geometry. Wear induced damage is a function of the material characteristics and testing

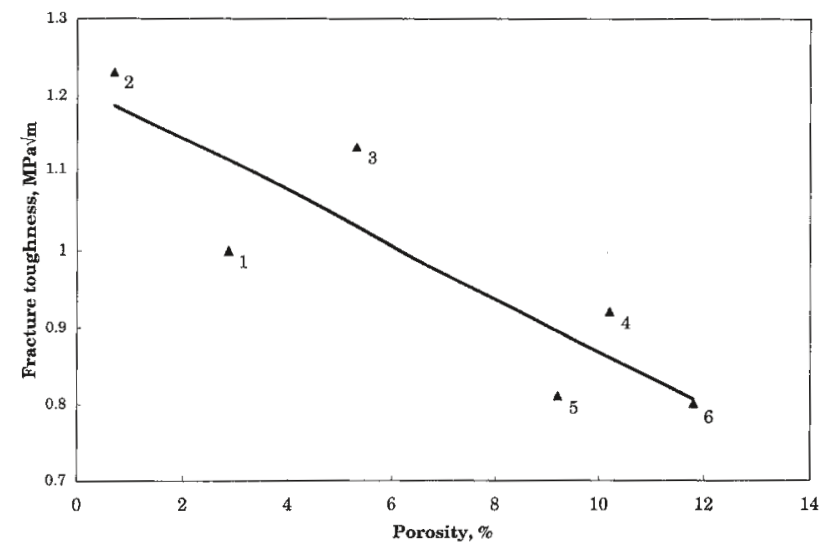

Figura3 - NWL como una función de la porosidad de las capas de esmalte: los números de la estructura corresponden a las muestras. 6000 rev. ( $\square), 12000$ revv.

Figure 3 - NWL as a function of the porosity of the glaze layers: the numbers in the plot correspond to the samples. $6000 \mathrm{rev}$. ( $\square$ ), $12000 \mathrm{rev}$.

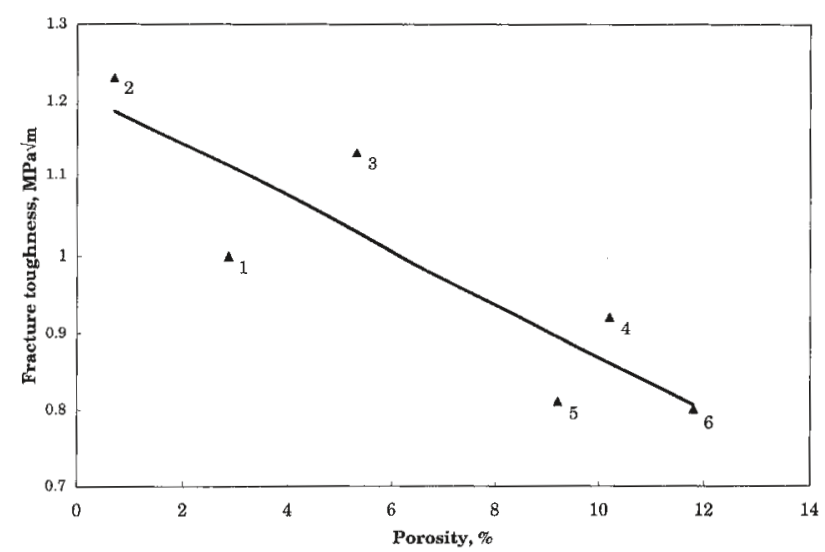

Figura 4 - NWL como una función de resistencia a la fractura: los números de la estructura corresponden a las muestras. $6000(\bigcirc)$, 12000 rev. ( ).

Figure 4 - NWL as a function of fracture toughness: the numbers in the plot correspond to the samples. $6000 \mathrm{rev}$ ( $\bigcirc), 12000 \mathrm{rev}$. 
ras capas de la superficie más compactas se ha excedido y que las características de la capa de esmalte se han hecho predominantes.

De nuevo la muestra 2, caracterizada por una capa de esmalte con la porosidad más baja y la resistencia a la fractura más alta, también muestra el NWL más bajo.

Por último, se pueden aportar algunas consideraciones acerca de los resultados de la clasificación PEI. Como se aprecia en la tabla IV, los productos sólo se dividen en dos clase, incluso aunque sus pérdidas de peso sean muy diferentes. Especialmente interesante es el resultado de la muestra 2, cuyo desgaste es significativamente menor que el de los otros productos, a pesar de que esto no se podía predecir basándose en su clase de PEI. Este resultado es una confirmación más de que la prueba PEI de la resistencia a la abrasión de la superficie sólo proporciona una evaluación de las características estéticas y aporta pocos datos acerca del comportamiento ante el desgaste (1).

Los resultados ilustran claramente la importancia de las características físicomecánicas de los materiales y del proceso industrial mediante el cual se fabrican. Si no estos parámetros no se calculan de manera estricta, se pueden convertir en críticos para la respuesta ante el desgaste de la propia superficie del azulejo cerámico esmaltado. En lo que a esto respecta, la porosidad de la capa de esmalte parece jugar un papel muy importante.

\section{CONCLUSIONES}

Se han estudiado las posibles relaciones entre la dureza de la superficie de los Vickers, la resistencia a la fractura, la porosidad atrapada en la capa de esmalte y la respuesta ante el desgaste de los azulejos cerámicos esmaltado monococidos destinados a la venta. Los resultados obtenidos llevan a las siguientes consideraciones:

La dureza de los Vickers de la propia superficid no parece afectar a la eliminación de material, que demostró ser casi constante para todos los productos.

La resistencia a la fractura y la porosidad de las capas de esmalte tienen una influencia importante en la respuesta al desgaste: la pérdida de material disminuye con el aumento de $\mathrm{K}_{\mathrm{IC}} \mathrm{y}$ el descenso de la porosidad.

Los parámetros que indican la naturaleza del material, así como la tecnología de esmalte, pueden ser importantes a la hora de definir las características microestructurales y las características de la capa de esmalte.

Las capas de esmalte compactas, independientemente de la composición inicial, permiten conseguir valores relativamente altos de resistencia a la fractura que, sucesivamente, significa un mejor comportamiento ante el desgaste.

Ensayos como los que se han llevado a cabo en esta investigación se pueden considerados una herramienta útil para predecir el comportamiento ante el desgaste de los azulejos cerámicos esmaltados, al mismo tiempo que proporcionan información acerca del proceso de cocción y la posibilidad de mejorar el comportamiento y la respuesta al desgaste de estos productos. parameters, in this case the number of revolutions.

The NWL after 6000 revolutions shows a similar trend to that registered after 12000, meaning that the transient phase related to the removal of the first more compact surface layers has been exceeded and the bulk glaze characteristics have become predominant.

Again sample 2, characterised by a glaze layer with the lowest porosity and the highest fracture toughness, also shows the lowest NWL.

Finally some considerations on the results of the PEI classification can be drawn. As seen in table IV, the products fall into only two classes, even though their weight losses are very different. Particularly interesting is the result of sample 2, whose wear is significantly lower than that of the other products, even though this would not be predicted on the basis of its PEI class. This result is further confirmation that the PEI test for resistance to surface abrasion only provides an evaluation of the aesthetic characteristics and gives little indication of the wear performance (1).

These results clearly illustrate the importance of the physical-mechanical characteristics of the materials and the industrial process with which they are produced. If these parameters are not strictly controlled, they can become critical for the wear response of the proper surface of glazed ceramic tile. In this regard, the porosity of the glaze layer seems to play a very important role.

\section{CONCLUSIONS}

Possible relationships between Vickers surface hardness, fracture toughness, porosity trapped in the glaze layer and wear response of commercially available single-fired glazed ceramic tile were studied. The results obtained lead to the following considerations:

- Vickers hardness of the proper surface does not seem to affect material removal, which was found to be almost constant for all the products.

- Fracture toughness and porosity of the glaze layers have a considerable influence on the wear response: material loss decreases with increasing $\mathrm{K}_{\mathrm{IC}}$ and decreasing porosity.

- Parameters indicating the nature of the material as well as the glazing technology can be important to define the microstructural features and characteristics of the glaze layer.

- Compact glaze layers, independently of their starting composition, allow relatively high values of fracture toughness to be reached, which, in turn, means better wear behaviour.

Tests like those carried out in this research can be considered a useful tool to predict the wear behaviour of glazed ceramic tile as well as provide information on the firing process and possibility of improving the performance and wear response of these products. 


\section{BIBLIOGRAFÍA / REFERENCES}

1. G. Carani, A. Tucci, P. Cienerali, L. Esposito, and S. Nuzziello, "Surface Degradation and Vickers Indentation Hardness of Glazed Ceramic Tiles", Ceram. Eng. Sci. Proc. 15 [11 129- 137 (1994).

2. R.W. Rice, "Micromechanics of Merostructural Aspects of Ceramic Wear", Ceram. Eng. Sci. Proc. 6 [7-81 940-958 (1985)

3. M.W. Hawman, P.H. Cohen, J.C. Conway and R.N. Pangborn, "The Effect of Grinding on the Flexural Strength of a Sialon Ceramic", J. Mater. Sci. 20482 490 (1985).

4. R. Samuel, S. Chandrasekar, T.N. Farris and R.H. Licht, "Effect of Residual Stresses on the Fracture of Ground Ceramics", J. Am. Ceram. Soc. 72 19601966 (1989).

5. R.F. Cook, B.R. Lawn, T.P. Dabbs and P. Chantikul, "Effect of Machining Damage on the Strength of a Glass-Ceramic", J. Am. Ceram. Soc. 64 C 121-122 (198 1).

6. M.A. Moore and F.S. King, "Abrasive wear of brittle solids", Wear 60 123-140 (1980).

7. A.G. Evans and D.B Marshall, "Wear Mechanisms in Ceramics", pp. 439-452 in Fundamental of Friction and Wear of Materials". Ed. D.A. Rigney, ASM, Metal Park Ohio (USA) 1981.

8. M. Miranda-Martinez, R.W. Davidge and F.L. Mey, “Wet erosive wear of ceramics", pp. 949-954 in Third Euro-Ceramics V. 3. Ed. P. Duran and F. Fernandez; Faenza Editrice Ibérica, S.L., (E) 1993.

9. H.H.K. Xu, S. Jahanmir, L.K. Ives, "Mechanisms of Material Removal in Abrasive Machining of Ceramics", Interceram 47 380-385 (1998).

10. G. Nicoletto, A. Tucci, L. Esposito, "Fracture Damage during Sliding Wear of Ceramics", pp. 147-156 in Proc. of the IGF 12 - XII Convegno Nazionale Gruppo Italiano Frattura, Parma (I), June 1996.
11. Project PL-95-2122 - Contract SMT4-CT95-2041 - “Measurement of Surface Hardness of Ceramic Tiles by Vickers Indentation Method". Final Report (1999)

12. M. Miranda-Martinez and F.L. Riley, "Wet Abrasive Wear of Advanced Technical Ceramics", Br. Ceram. Trans. J. 90 118-121 (1991).

13. S.J. Bull and D.S. Rickerby, "Evaluation of Coating", pp. 315-342 in Advanced Surface Coatings: A Handbook of Surface Engineering. Ed. D. S. Rickerby and A. Matthews, Blackie, Glasgow (UK) 1991.

14. B.R. Lawn, A.G. Evans, D.B. Marshall, "Elastic/ Plastic Indentation Damage in Ceramics: The Median/Radial Crack System", J. Am. Ceram. Soc. 63 [9-101 574- 581 (1980)

15. A. Moreno, E. Montiel, J. Toledo, A. Escardino, “Relation between the mechanical properties of ceramic glazes and their behaviour on subjecting them to external stresses", pp. 305-316 in Proc. of the "Qualicer 92, II World Congress on Ceramic Tile Quality", Castellón (E) (1992).

16. R. Chinn, "Grain Sizes of Ceramics by Automatic Image Analysis", J. Am. Ceram. Soc. 77 [2] 589- 592 (1994).

17. European Standard EN 154. M7 Norme sulle piastrelle di ceramica per rivestimento di pavimenti e pareti Norme Europee, in Italian. Ente Nazionale Italiano di Unificazione, Miano (I) (1995).

18. D. Bigoni, A. Movchan, L. Esposito, S. Serkov, M. Valentini, "Crack Propagation in Brittle Elastic Solids with Defects", pp. 59-67 in Proc. of the IGF 12 - XII Convegno Nazionale Gruppo Italiano Frattura, Parma (I), June 1996.

19. L. Esposito, G. Carani, A. Tucci, S. Nuzziello and P. Generali, "Vickers Indentation Method Applied to the Characterisation of Ceramic Glazes", Ceram. Eng. Sci. Proc. 15 [1] 146-159 (1994). 